\title{
Риски распространения в Российской Федерации новых вирусных болезней томата
}

\author{
Risks of new tomato virus diseases spreading in the Russian Federation
}

Игнатов А.Н., Гриценко В.В., Джалилов Ф.С.-У.

\section{Аннотация}

Анализ наиболее вредоносных вирусных фитопатогенов на предприятиях защищенного грунта показывает, что проникновение новых видов с семенами и готовой продукцией из других регионов и стран подвергает производство томата большому риску. Главная проблема выявления заражения - длительный инкубационный период для вирусных болезней и необходимость инструментальных методов идентификации патогена. Достижения в области иммунологического и молекулярного анализа вирусов растений позволяют технически обнаруживать большое число новых видов и биотипов, сводя проблему диагностики к вопросу экономической целесообразности такого анализа. Для того, чтобы определить минимальный набор диагностируемых видов, необходимо оценить разнообразие вирусов, поражающих томат, и риск их распространения в тепличных хозяйствах Российской Федерации. Авторы анализируют ранее опубликованные данные по зараженности томата в мире и РФ для определения наиболее опасных вирусов, которые могут нанести существенный ущерб производству томата. Если учитывать число видов и наносимый ущерб, то на первых местах находятся ДНК-вирусы семейств Geminiviridae (включая род Begomovirus) и РНК-вирусы родов Tobamovirus, Cucumovirus и некоторых других. Среди вирусов с максимальным потенциальным риском - бегомовирус желтой курчавости листьев томата (TYLCV). Проблемы, вызываемые бегомовирусами, в том числе TYLCV и его многочисленными локальными вариантами, связаны в первую очередь с распространением биотипа В табачной белокрылки. Он способен размножаться на широком круге растений и служит своеобразным «аккумулятором» вирусов - может переносить около 100 различных видов. Вирус коричневой (бронзовой) морщинистости плода (ToBRFV, род Tobamovirus) был обнаружен в 2015 году в Иордании, и представляет значительный риск для всего производства томатов РФ. Поскольку противовирусные препараты недоступны, стратегии борьбы с ними основываются на генетической устойчивости растений, уничтожении переносчиков и на карантинных мерах по предотвращению заболеваний, а также на дезинфекции теплиц. Расширение международной торговли растительными продуктами повысило риск ввоза новых вирусов в растительные экосистемы с идеальными условиями для заражения растений, развития вирусов и их сохранения в течение круглого года. Изменение климатических условий может способствовать успешному распространению привнесенных вирусов и их переносчиков в экосистемы открытого грунта.

Ключевые слова: вирусы, переносчики, растения, агроценоз теплиц.

Для цитирования: Игнатов А.Н., Гриценко В.В., Джалилов Ф.С.-У. Риски распространения в Российской Федерации новых вирусных болезней томата // Картофель и овощи. 2020. №5. С. 3-10. https://doi.org/10.25630/PAV.2020.80.51.001
Ignatov A.N., Gritsenko V.V., Dzhalilov F.S.-U.

\section{Abstract}

Analysis of the most harmful viruses pathogenic for tomato in greenhouses shows that the spreading of new species occurs with seeds and fruits from other regions and countries, and exposes tomato production to a great risk. Long latent period for virus diseases and the need for instrumental methods of pathogen identification are the main problem for identifying the pathogen and source of infection, and decision making for its control Advances in the field of immunological and molecular analysis of plant viruses allow technically a detection of a number of virus species and biotypes, reducing the problem of diagnosis to the question of economic feasibility of such work. In order to determine the minimum set of diagnosed virus species, the diversity of viruses that infect tomatoes and the risk of their spreading in greenhouses in the Russian Federation as assayed. We analyzed some previously published data on tomato viruses across the world and the Russian Federation to determine the most harmful viruses that can cause significant damage to tomato production. Taking in account the number of species and the damage caused, the first places are hold by DNA viruses Geminiviridae (including genus Begomovirus), and RNA-virus genera Tobamovirus, Cucumovirus and some others. Among the viruses with the highest potential risk is the tomato leaf yellow curl virus (TYLCV). Problems caused by begomoviruses, including TYLCV and related species are primarily associated with the spread of the tobacco whitefly biotype $B$. It is able to reproduce on wide range of host plants and serves as reservoir of viruses - it can a vector for about 100 species. Tomato brown rugose fruit virus (ToBRFV, genus Tobamovirus) was discovered in 2015 in Jordan, and represents a significant risk for the entire production of tomatoes in the Russian Federation. Antiviral pesticides are not available, and control strategies rely on genetic resistance or phytosanitary measures to prevent diseases, or on eradication of diseased crops and vectors, and greenhouses sanitation. Increasing international travel and trade of plant materials enhances the risk of introducing new viruses and their vectors into production systems. In addition, changing climate conditions can contribute to a successful spread of newly introduced viruses or their vectors to agro-ecosystems in areas that were previously free of those viruses.

Key words: viruses, vectors, plants, greenhouse agroecosystem.

For citing: Ignatov A.N., Gritsenko V.V., Dzhalilov F. S.-U. Risks of new tomato virus diseases spreading in the Russian Federation. Potato and vegetables. 2020. No5. Pp. 3-10. https://doi.org/10.25630/ PAV.2020.80.51.001 (In Russ.).
$\mathrm{M}$ ировое производство томата в 2017 году достигло 182258 тыс. т, показывая ежегодный прирост около 1,6\% [1]. По стоимости томат (Solanum lycopersicum) занимает $72 \%$ общего производства свежей овощной продукции. Одна из главных проблем производства томата - высокая восприимчивость культуры к вирусным болезням. Томат поражается 136 видами вирусов - существенно больше, чем для таких родственных культур, как перец (Capsicum annuum), картофель (S. tuberosum) или баклажан (S. melongena) [2]. Значительную роль в распространении вирусов играет тепличная культура томата. 
Цель: на основании анализа имеющихся данных охарактеризовать риски распространения новых вирусных болезней томата в Российской Федерации.

Условия, материалы и методы исследований

Методы обнаружения вирусов в растениях

Еще недавно анализ присутствия неизвестных вирусов в растениях зависел от методов инокуляции индикаторных видов растений и электронной микроскопии. Использование иммунологических методов, основанных на реакции антигенов вируса с гомологичными антителами животных, ускорило анализ, но потребовало длительной и трудоемкой подготовительной работы. Развитие методов ПЦР-анализа позволило расширить список анализируемых видов в каждой лаборатории и заново создать систематику вирусов, основанную на сходстве их геномов. Тем не менее, главным ограничением является то, что мы определяем наличие в растении только ограниченного числа ожидаемых видов патогена, и очень часто упускаем факты смешанного заражения или появления новых для конкретного растения или региона видов вирусов.

Применение методов секвенирования следующего поколения (next generation sequencing (NGS)) дает возможность определять новые вирусы растений без предварительной информации о вероятном заражении, основываясь только на сходстве последовательностей их нуклеиновых кислот с образцами Генбанка. Эти методы уже применяются в тестовом режиме службами защиты и карантина растений в некоторых странах, и вероятно, получат широкое распространение через несколько лет.

\section{Результаты исследований}

По итогам 2019 года площадь зимних теплиц в Российской Федерации составила не менее 2,8 тыс. га. Общий сбор овощей в защищенном грунте в 2019 году достиг 1240 тыс. т. [3]. Но, несмотря на это, проблемы защиты растений от болезней остаются даже при улучшенной технологии выращивания тепличных культур. В последние годы на территории России отмечается усиление вредоносности вирусных болезней растений из-за недостатка своевременной диагностики вирусов в посевном материале и на растениях, а также нехватки эффективных мер борьбы с ними [4].
А.К. Ахатов и Е.А. Ахатов описали факторы технологии, способствующие распространению вирусов в защищенном грунте: регулярный сбор продукции с молодых растений без мер предосторожности и интерплантинг создают условия для перезаражения растений; короткий разрыв между оборотами не дает достаточно времени для полной дезинфекции и дезинсекции; теплицы работают круглогодично, поддерживая популяции патогена и/или его переносчика [5]. К этому можно добавить практику отказа от изолирующих сеток в рассадных отделениях для улучшения вентиляции в летний сезон и недостаток общей изоляции растений от насекомых-переносчиков вирусов.

Анализ известных случаев появления новых вирусов на предприятиях защищенного грунта показывает, что основные пути проникновения вирусов - семена и посадочный материал, готовая продукция из других регионов и стран, складируемая в пределах тепличных хозяйств, насекомые-переносчики и рабочие, контактировавшие с зараженными растениями вне хозяйства. Главная проблема выявления источника заражения - длительный инкубационный период вирусных болезней и необходимость инструментальных методов (ИФА, ПЦР) для идентификации патогена.

Вирусы, поражающие томат

Число видов вирусов, поражающих наиболее важные культуры в закрытом грунте, исчисляется десятками. Современными инструментальными методами, например, такими как NGS, можно определять все присутствующие в растении вирусы, но по экономическим причинам, сейчас ПЦР или иммунологический анализ проводится только для наиболее вредоносных.

На проявление симптомов, динамику развития и вредоносность вирусных болезней влияет комплекс факторов: сортовые особенности и возраст растений, условия выращивания (диапазон температур) и освещенность. Наличие других вирусов в растении может полностью изменить симптомы болезни и усилить их вредоносность во много раз. Необходимо учитывать и то, что, несмотря на видоспецифичные названия вирусов, они способны заражать многие виды растений различных семейств, нередко развиваясь в них без проявления внешних симптомов болезни (т.н. латентное заражение) [6].
В табл. 1 приведены основные вирусы, поражающие томат в мире, по данным Европейской и Средиземноморской организации по карантину и защите растений (EPPO, European and Mediterranean Plant Protection Organization) [7]. Если учитывать число видов и наносимый ущерб, то на первых местах находятся ДНК-вирусы семейств Geminiviridae (включая род Begomovirus) и РНК-вирусы родов Tobamovirus, Cucumovirus, а также некоторых других.

Семейство Geminiviridae включает 9 родов и более 360 видов вирусов [8]. Эти вирусы вызывают на растениях симптомы желтой мозаики, желтой крапчатости, курчавости листьев, карликовости, стрика и значительно уменьшают урожайность томата. Вирусы этой группы имеют геном, состоящий из одноцепочечной ДНК. Вирусы родов Mastrevirus и Curtovirus переносятся различными видами цикадок, штаммы возбудителя ложной курчавости верхушки томата (TSCTV, род Tороcuvirus) также переносит цикадка Micrutalis malleifera. Виды рода Begomovirus переносит табачная (хлопковая) белокрылка Bemisia tabaci. Ущерб, наносимый этими вирусами растениеводству, огромен. Геномы разных видов бегомовирусов при заражении одного растения способны рекомбинировать и давать новые генотипы, более приспособленные к конкретному растению-хозяину. Ареал распространения вирусов Geminiviridae относительно недавно затронул Российскую Федерацию, и, в первую очередь, это связано с изменением климата и заселением территории страны насекомыми-переносчиками этих вирусов [9]. Предполагается, что указанные вирусы происходят от плазмид фитоплазм [10]. Известны также факты включения их ДНК в геномы растений [11].

Известны 37 видов рода тобамовирусы (Tobamovirus, сем. Virgaviridae) поражающих большое число различных культур. К этому роду относятся возбудители мозаики табака (TMV) и томата (ToMV). В большинстве случаев тобамовирусы вызывают некротические поражения листьев и плодов томата [12]. Вирусы передаются механически и семенами, отличаются высокой устойчивостью в окружающей среде. Три группы тобамовирусов специализируются на различных семействах растений - на пасленовых, 
Таблица 1. Вирусы, поражающие томат со значительными экономическими потерями [7]

\begin{tabular}{|c|c|c|c|c|}
\hline Заболевание & Вид & Род & Код & в РФ* \\
\hline \multicolumn{5}{|c|}{ Семейство Geminiviridae } \\
\hline $\begin{array}{l}\text { Курчавость верхушки, } \\
\text { пожелтение }\end{array}$ & Beet Curly Top Virus & Curtovirus & BCTV & + \\
\hline Ложная курчавость верхушки & Tomato pseudo-curly top virus & Topocuvirus & TPCTV & - \\
\hline Крапчатость & Tomato mottle geminivirus & Begomovirus & ToMoV & - \\
\hline Желтая курчавость листьев & Tomato yellow leaf curl virus & Begomovirus & TYLCV & - \\
\hline Курчавость листьев томата & $\begin{array}{l}\text { Tomato leaf curl New Delhi } \\
\text { virus }\end{array}$ & Begomovirus & ToLCNDV & - \\
\hline $\begin{array}{l}\text { Сильная морщинистость } \\
\text { плода }\end{array}$ & Tomato severe rugose virus & Begomovirus & ToSRV & - \\
\hline $\begin{array}{l}\text { Карликовая курчавость } \\
\text { листьев }\end{array}$ & Tomato dwarf leaf curl virus & Begomovirus & TODLCV & - \\
\hline Золотая мозаика & Tomato golden mosaic virus & Begomovirus & TGMV & - \\
\hline Желтая мозаика & Tomato yellow mosaic virus & Begomovirus & TOYMV & - \\
\hline $\begin{array}{l}\text { Желтая штриховатость } \\
\text { жилок }\end{array}$ & $\begin{array}{l}\text { Tomato yellow vein streak } \\
\text { virus }\end{array}$ & Begomovirus & TOWSV & - \\
\hline \multicolumn{5}{|c|}{ Семейство Virgaviridae } \\
\hline $\begin{array}{l}\text { Мозаика/внутренний не- } \\
\text { кроз плодов }\end{array}$ & Tobacco mosaic virus & Tobamovirus & TMV & + \\
\hline Мозаика & Tomato mosaic virus & Tobamovirus & ToMV & + \\
\hline $\begin{array}{l}\text { Коричневая морщинис- } \\
\text { тость плода }\end{array}$ & $\begin{array}{l}\text { Tomato brown rugose fruit } \\
\text { virus }\end{array}$ & Tobamovirus & ToBRFV & - \\
\hline \multicolumn{5}{|c|}{ Семейство Bromoviridae } \\
\hline Аспермия & Tomato aspermy virus & Cucumovirus & TAV & + \\
\hline Папоротниковый лист & Cucumber mosaic virus & Cucumovirus & CMV & + \\
\hline Вирус пестроперой мозаики & Gayfeather mild mottle virus & Cucumovirus & GFMMV & + \\
\hline \multicolumn{5}{|c|}{ Семейство Secoviridae } \\
\hline Некротическая пятнистость & $\begin{array}{l}\text { Capsicum annuum necrotic } \\
\text { spot virus }\end{array}$ & Nepovirus & CaNSV & + \\
\hline Вирус мозаики резухи & Arabis mosaic virus & Nepovirus & ArMV & + \\
\hline Кольцевая пятнистость & Tomato ringspot virus & Nepovirus & TORSV & + \\
\hline Черная кольцевая пятнистость & Tomato black ring virus & Nepovirus & TBRV & + \\
\hline \multicolumn{5}{|c|}{ Potyviridae } \\
\hline $\begin{array}{l}\text { Колумбийский Датура } \\
\text { вирус }\end{array}$ & Columbian datura virus & Potyvirus & CDV & - \\
\hline Гравировка & Tobacco etch virus & Potyvirus & TEV & + \\
\hline Вирус картофеля Y & Potato virus $Y$ & Potyvirus & PVY & + \\
\hline \multicolumn{5}{|c|}{ Alphaflexiviridae } \\
\hline Мозаика пепино & Pepino mosaics virus & Potexvirus & PepMV & + \\
\hline Х вирус картофеля & Potato virus $X$ & Potexvirus & PVX & + \\
\hline \multicolumn{5}{|c|}{ Closteroviridae } \\
\hline Хлороз & Tomato chlorosis virus & Crinivirus & ToCV & - \\
\hline Инфекционный хлороз & Tomato infectious chlorosis virus & Crinivirus & TICV & - \\
\hline \multicolumn{5}{|c|}{ Прочие } \\
\hline $\begin{array}{l}\text { Некроз/желтая мозаика } \\
\text { томата }\end{array}$ & Alfalfa mosaic virus & Alfamovirus & AMV & + \\
\hline Пожелтение верхушки & Tomato yellow top virus & Luteovirus & TYTV & - \\
\hline Скручиваемость листьев & Potato leafroll virus & Polerovirus & PLRV & + \\
\hline Бронзовость томата & Tomato spotted wilt virus & Tospovirus & TSWW & + \\
\hline Вирус Торрадо & Tomato torrado virus & Torradovirus & ToTV & - \\
\hline Кустистая карликовость & Tomato bushy stunt virus & Tombusvirus & TBSV & - \\
\hline
\end{tabular}

тыквенных и бобовых и на капустных культурах [13].

Род Cucumovirus (семейство Bromoviridae) включает типовой вид вирус огуречной мозаики (CMV), поражающий более 1200 видов растений и 100 семейств двудольных и однодольных, включая однолетние овощные, декоративные культуры, многолетние древесные и кустарники. Растения томата, пораженные CMV на ранней стадии роста, желтеют и замедляют рост. Симптомы на листьях на поздних стадиях развития очень напоминают мозаику, вызываемую ToMV (рис. 1), но наиболее характерный симптом для CMV - нитевидность листьев и израстание листовой пластинки. Иногда симптомы проявляются только на самых молодых листьях растения. Плоды на пораженных растениях меньше по размеру, они созревают с опозданием и часто имеют некрозы. Патоген передается семенами, механически, при прививке, и тлями-переносчиками неперсистентным способом [14].

Род Nepovirus (семейство Secoviridae) состоит из 36 видов, включая 4 вируса, поражающих пасленовые культуры и встречающиеся в РФ (табл. 1). Неповирусы передаются нематодами, клещами и трипсами [15, 16]. Потексивирусы (род Potexvirus) - механически передаваемые вирусы, поражающие в том числе и томат (РерMV первоначально выделен из пепино - S. muricatum). Род Crinivirus включает виды TICV и ToCV, передаваемые полуперсистентным способом табачной белокрылкой (Bemisia tabaci), популяция которой резко выросла в последние десятилетия, и оранжерейной белокрылкой Trialeurodes vaporariorum, активно распространяющейся на культурах открытого грунта летом и зимующей в тепличных комбина$\operatorname{Tax}[17]$.

K потивирусам (Potyvirus) относят PV, колумбийский датура вирус (CDV) и вирус гравировки томата (TEV). Особая опасность PVY состоит в его широком распространении на посадках товарного картофеля, и в распространении несколькими видами тли, способных проникать в теплицы и перезаражать растения томата во время летнего сезона.

Роль смешанных вирусных инфекций

По данным Н. Чанг, более 50\% заражений томата представлены комплексами нескольких вирусов: двух (обычно TMV+CMV, TMV+PVX, ToMV+PVX, ToMV+PVY); 3-X 
Таблица 2. Распространенность вирусов, поражающих томат в Российской Федерации [18, 21]

\begin{tabular}{|c|c|c|c|}
\hline \multirow{2}{*}{ Патоген } & \multirow{2}{*}{ Код } & \multicolumn{2}{|c|}{ Частота распространения, \% } \\
\hline & & Живаева [21] & Чанг [18] \\
\hline Вирус аспермии томата & TAV & $<1,5$ & 3,9 \\
\hline Вирус бронзовости томата & TSWV & 4,0 & 4,9 \\
\hline Вирус гравировки табака & TEV & 0 & - \\
\hline Вирус желтой курчавости листьев томата & TYLCV & 0 & 0 \\
\hline Вирус кустистой карликовости томата & TBSV & $<1,5$ & - \\
\hline Вирус мозаики резухи & ArMV & 2,9 & 0 \\
\hline Вирус мозаики пепино & PepMV & 2,4 & $<2,5$ \\
\hline Вирус мозаики томата (ToMV), & ToMV & 20,9 & 70,0 \\
\hline Вирус огуречной мозаики (CMV), & CMV & 8,9 & 31,4 \\
\hline Вирус табачной мозаики & TMV & 21,2 & 19,0 \\
\hline Вирус хлороза томата & ToCV & 0 & $<2,5$ \\
\hline Вирус черной кольцевой пятнистости томата & TBRV & $<1,5$ & 0 \\
\hline Вирус штриховатости табака & TSV & 3,9 & $<2,5$ \\
\hline Ү вирус картофеля & PVY & 5,1 & 18,4 \\
\hline Х вирус картофеля & PVX & 10,8 & 25,9 \\
\hline М вирус картофеля & PVM & - & $<2,5$ \\
\hline Вирус мозаики люцерны & AMV & - & 4,0 \\
\hline Вирус некроза табака & TNV & - & $<2,5$ \\
\hline Вирус некроза томата & TNEV & - & $<2,5$ \\
\hline Вирус кольцевой пятнистости томата & ToSRV & - & 0 \\
\hline Вирус кольцевой пятнистости табака & TRSV & - & 0 \\
\hline
\end{tabular}

* «-» нет данных

(ToMV+CMV+TAV; ToMV+CMV+PVX), или четырех (ToMV+CMV+TAV+PVX) возбудителей [18]. При этом симптомы, как правило, изменяются - развиваются более суровые (тяжелые) признаки. В случаях поражения растений TMV+PVX - мозаика, морщинистость, некрозы, скручивание листьев, стрик стебля и плодов, при смешанной инфекции TVM+PVY - некрозы, деформация листьев, штрихова-

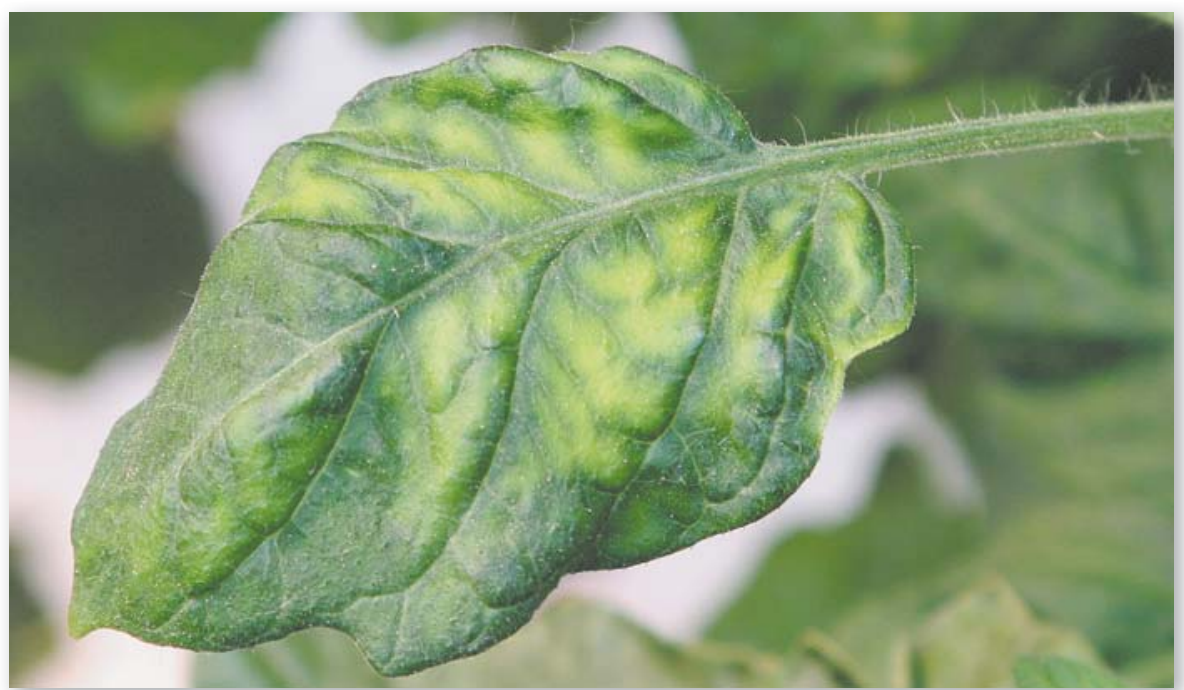

Рис. 1. Лист растения томата, пораженный вирусом огуречной мозаики. Фотография предоставлена А.К. Ахатовым. Публикуется с разрешения автора. ные инструментальными методами в последнее десятилетие (20102019) показывают, что в хозяйствах РФ распространен достаточно широкий спектр вирусов. При этом основным компонентом структуры видового состава возбудителей остаются тобамовирусы. Серологическое тестирование образцов растений томата, включая и бессимптомные образцы, свидетельствует о высокой частоте встречаемости вирусов в условиях защищенного грунта. В работе Т.С. Живаевой растения томата тестировали на наличие 15 вирусов (табл. 2) [21]. Установлено, что наиболее широко распространены вирусы TMV и ToMV, которые были выявлены соответственно в 21,2\% и 20,9\% протестированных растений. Реже встречались PVX, CMV, PVY, TSWV, TSV, ArMV и PepMV (от 2,4 до 10,8\%). Остальные вирусы встречались значительно реже.

В работе Чанг, при анализе томата на наличие 15 вирусов (список частично не совпадает с предыдущим исследованием), было выявлено больше тобамовирусов - вирус мозаики томата встречался в $70 \%$ образцов, в вирус мозаики табака в 19,7\% [18]. К числу доминирующих вирусов были также отнесены вирусы Х и У картофеля (соответственно в 25,9\% и 18,4\% образцов). Высокая встречаемость $(31,4 \%)$ отмечена для вируса обыкновенной мозаики огурца (CMV). Более 50\% зараженных образцов были представлены комплексами 2-4 вирусов.

При сравнении с обследованиями, выполненными за рубежом примерно в те же годы, очевидны определенные закономерности в распределении вирусов томата в РФ. Так, в Сербии, при анализе образцов на наличие 12 вирусов в начале 2010-х, было показано доминирование $\mathrm{CMV}$, PVY, AMV и TSWV (бронзовость) 42, 1, 40,0, 11,0, и 8,6\% соответственно. А тобамовирусы были обнаружены только на 2,3\% (ToMV) и 1,3\% (TMV) обследованных растений [22]. Вероятно, это связано как с большей распространенностью насекомыхпереносчиков, так и со значительным резервом данных вирусов в окружающих посадки томата ландшафтах.

Если к известным патогенам есть отработанные методы диагностики зараженности растений, семян, воды, и, в некоторых случаях, - препараты биологической защиты или устойчивые сорта и гибриды, то новые возбудители болезней тепличных растений всегда представля- 


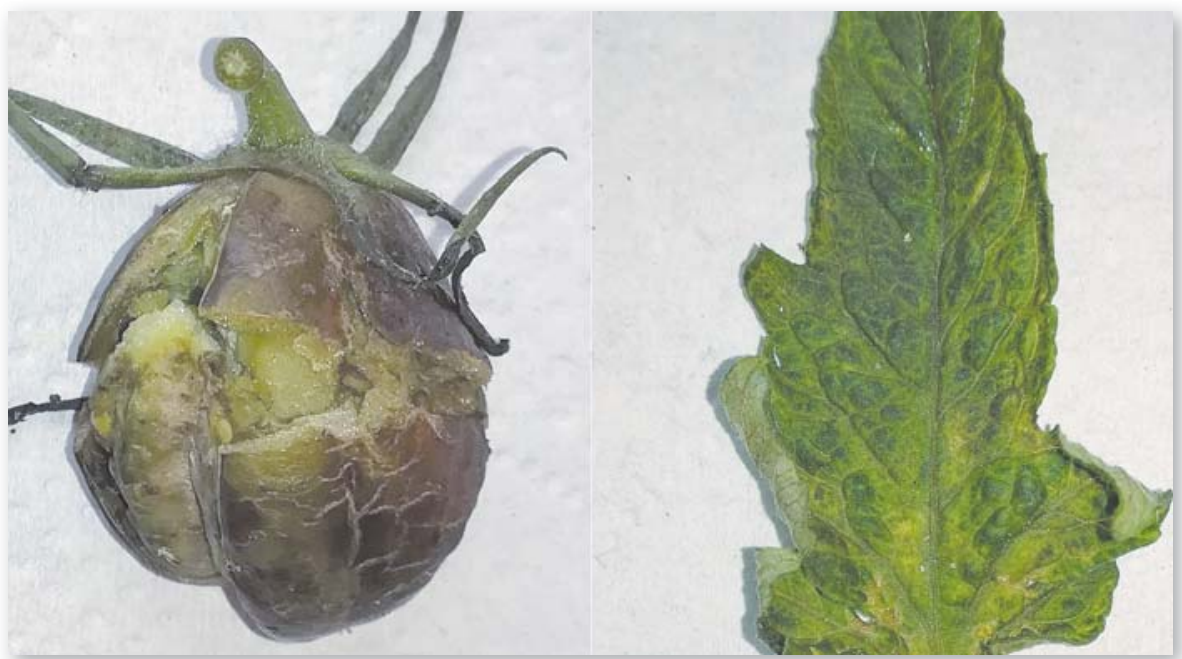

Рис. 2. Плод и лист растения томата пораженного вирусом мозаики томата и Ү вирусом картофеля. Фото А.Н. Игнатова

ют опасность наивысшего уровня, в первую очередь, из-за длительного периода их идентификации.

Новые опасные вирусные болезни в теплицах

Среди вирусов с максимальным потенциальным риском - бегомовирус желтой курчавости листьев томата (Tomato yellow leaf curl begomovirus TYLCV) (рис. 3). Главное растение-хо-

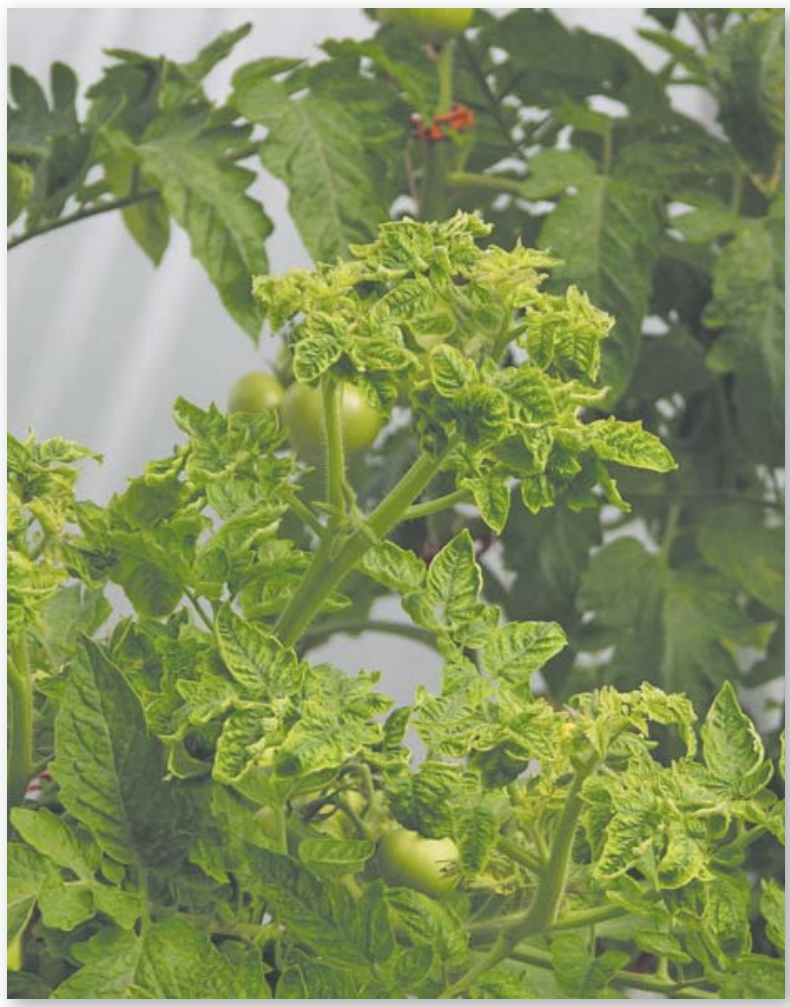

Рис. 3. Растение томата, пораженное вирусом желтой курчавости листьев. Фото Д. Феррин (Don Ferrin, Louisiana State University Agricultural Center). Публикуется с разрешения www.bugwood.org зяин вируса - томат и другие пасленовые, но он также поражает растения семейств тыквенные и бобовые. Вирус переноситься табачной (хлопковой) белокрылкой (Bemisia tabaci) с персистентным типом передачи. Этот переносчик отмечен в Крыму и на Черноморском побережье РФ. Растения томата, заразившиеся в молодом возрасте, останавливаются в росте и не образуют плодов. Последующие листья хлоротичные, с деформированными пластинками, закрученными вверх краями и искривлениями между жилками [23].

Проблемы, вызываемые бегомовирусами, в том числе TYLCV и его многочисленными локальными вариантами, связаны в первую очередь с распространением биотипа В табачной белокрылки B. tabaci. Этот биотип способен размножаться на широком круге растений и служит своеобразным «аккумулятором» вирусов известно, что он может переносить около 100 различных видов. Более того, известен факт, что ряд вирусов с персистентной передачей (например, вирус скручиваемости листьев картофеля PLRV) обеспечивает более эффективную и длительную передачу других вирусов томата.
Вирус коричневой (бронзовой) морщинистости плода (Tomato Brown Rugose Fruit Virus - ToBRFV, род Tobamovirus) был обнаружен в 2015 году в Иордании, но годом раньше заболевание было отмечено в Израиле. Вирус вызывает мозаичный рисунок на листьях, а также нарушение окраски и деформацию плодов. Гены устойчивости против других тобамовирусов неэффективны против ToBRFV. Он может передаваться с зараженными семенами, растениями и плодами, поливной водой, и при простом соприкосновении больных и здоровых растений. Устойчивость ToBRFV к неблагоприятным факторам такая же высокая как у вирусов табачной и томатной мозаики [7, 8]. Новый вирус представляет значительный риск для всей томатной отрасли РФ.

Многие пасленовые культуры (перец, табак, декоративные растения) заражаются этими вирусами без симптомов и служат постоянным источником инфекции для восприимчивых томатов.

\section{Выводы}

Наиболее вредоносные для производства томата в защищенном грунте вирусы наносят ущерб во всем мире - потери урожая от бегомовирусов, например, достигали 60\% от среднегодового производства томата $[6,25]$. Ряд бегомовирусов, кринивирусы TICV, ToCV, новый патоген ToBRFV уже включены в списки карантинных объектов в ряде стран и зараженные семена и растения должны быть остановлены на границе, а при обнаружении внутри страны - уничтожены. Другие, например, PерMV, не допускаются в семенном материале [24].

Гены устойчивости к бегомовирусам (Ту-гены) известны в ряде дикорастущих пасленовых, и были уже переданы в коммерческие сорта томата [26]. Но, к большинству новых вирусов источники надежной устойчивости еще не найдены, или селекция линий и сортов, приемлемых для производства, еще не завершена. Поэтому основное внимание должно быть уделено профилактике вирусных болезней и борьбе с их переносчиками [25]. Ключевой фактор в разработке мер борьбы с вирусами томата в защищенном грунте своевременная и точная диагностика новых видов вирусов и информирование о возможных рисках как производителей овощей в защищенном грунте, так и специалистов по защите растений. 


\section{Библиографический список}

1.Food and Agricultural Organization, United Nations [Электронный pecypc] URL: http://www.fao.org/faostat/en/\#data/QC/. Дата обращения: 15.04.2020.

2.Brunt A.A. et al. Descriptions and Lists from the VIDE Database [Электронный ресурс] URL: http://image.fs.uidaho.edu/vide/refs. htm. Дата обращения: 20.08.1996.

3.Ассоциация «Теплицы России»: предварительные итоги 2019 года [Электронный ресурс] URL: http://rusteplica.ru/ predvaritelnye-itogi-goda/. Дата обращения: 15.04.2020.

4.Гришечкина Л.Д. Проблемы защиты овощных культур от болезней в теплицах // Защита и карантин растений. 2011. № 2. C. $16-18$.

5.Ахатов А.К., Ахатов Е.А. Наиболее вредоносные болезни овощных культур в современных тепличных комбинатах // Гавриш. 2014. №3. С. 16-23.

6. Hadidi A., Khetarpal R.K., Koganezawa H. Plant virus disease control. Minnesota: The American Phytopathological Society, 1998. $684 \mathrm{p}$.

7.EPPO Global Database [Электронный ресурc] URL: https:// gd.eppo.int/datasheets/. Дата обращения: 15.04.2020.

8.Zerbini F.M. et al. ICTV Report Consortium (February 2017). ICTV Virus Taxonomy Profile: Geminiviridae // The Journal of General Virology. 2017. Vol. 98 (2). Pp. 131-133.

9.Gray, Banerjee N. Mechanisms of Arthropod Transmission of Plant and Animal Viruses // Microbiol Mol Biol Rev. 1999. Vol. 63 (1). Pp. 128-148.

10.Krupovic M., Ravantti J.J., Bamford D.H. Geminiviruses: a tale of a plasmid becoming a virus // BMC Evol Biol. 2009. Vol.9 (112). doi:10.1186/1471-2148-9-112.

11.Discovery of ancient recombination between geminiviral DNA and the nuclear genome of Nicotiana sp. / E.R. Bejarano, A.M. Khashoggi, M. Witty, C.P. Lichtenstein // Proceedings of the National Academy of Sciences. 1994. Vol. 93. Pp. 759-764.

12.International Committee on Taxonomy of Viruses (ICTV) [Электронный ресурс] URL: https://talk.ictvonline.org/. Дата обращения: 15.04.2020.

13.Co-divergence and host-switching in the evolution of tobamoviruses / A.H. Stobbe, U. Melcher, M.W. Palmer, M.J. Roossinck, G. Shen // The Journal of General Virology. 2012. Vol. 93. Pt. 2. Pp. 408-418.

14.Bujarski J. et al. ICTV Report, Consortium (August 2019). ICTV Virus Taxonomy Profile: Bromoviridae // The Journal of General Virology. 2019. Vol. 100 (8). Pp. 1206-1207.

15.Nepovirus [Электронный ресурc] URL: http://www.dpvweb. net/notes/showgenus.php?genus= Nepovirus. Дата обращения: 15.04.2020.

16. Неповирусы (Picornavirales, Secoviridae, Nepovirus) на юге Дальнего Востока: результаты многолетнего мониторинга / Н.Н. Какарека, З.Н. Козловская, Ю.Г. Волков, Т.И. Плешакова, М.В. Сапоцкий, М.Ю. Щелканов // Юг России: экология, развитие. 2017. №4. С. 105-119.

17.Wintermantel W.M., Wisler G.C. Vector specificity, host range and genetic diversity of Tomato chlorosis virus // Plant Dis. 2006. Vol. 90. Pp. 814-819.

18.Чанг Ха Тхи Куинь. Распространение и патогенез вирусных заболеваний томата в условиях Вьетнама и России: автореф. дисс. ... канд. биол. наук. М., 2013. 20 с.

19.Verbeek M. et al. Identification and characterisation of Tomato torrado virus, a new plant picorna-like virus from tomato // Arch. Virol. 2007. Vol.152. Pp. 881-890.

20.First report of Tomato torrado virus infecting tomato in single and mixed infections with Cucumber mosaic virus in Panama / J.A. Herrera-Vasquez, A. Alfaro-Fernández, M.C. Córdoba-Selles, M.C. Cebrian, M.I. Font, C. Jordá // Plant Dis. 2009. Vol. 93. P. 198.

21.Живаева Т.С. Видовой состав вирусов огурца и томата в Европейской части Российской Федерации // Материалы 4-го съезда по защите растений. Санкт-Петербург: ВИЗР, 2019. С. 76

22. Nikolić D. et al. Viruses affecting tomato crops in Serbia // European Journal of Plant Pathology 2018. Vol. 152. Pp. 225-235.

23.Lemmetty A., Laamanen J., Soukainen M. Emerging virus and viroid pathogen species identified for the first time in horticultural plants in Finland in 1997-2010 // Agricultural and Food Science. 2011. Vol. 20. Pp. 29-41.

24.Commission Decision 2001/536/EC, 2004/200/EC [Электронный ресурc] URL: https://eur-lex.europa.eu/. Дата обращения: 15.04.2020.

25.Ахатов А.К. и др. Болезни и вредители овощных культур и картофеля. М.: КМК, 2013. 463 с.

26.Pyramiding of genes conferring resistance to Tomato yellow leaf curl virus from different wild tomato species / F. Vidavski, H. Czosnek, S. Gazit, D. Levy, M. Lapidot // Plant Breed. 2008. Vol. 127. Pp. 625-631.

\section{References}

1.Food and Agricultural Organization, United Nations [Web resource] URL: http://www.fao.org/faostat/en/\#data/QC/. Date of access: 15.04.2020.

2.Brunt A.A. et al. Descriptions and Lists from the VIDE Database [Web resource] URL: http://image.fs.uidaho.edu/vide/refs.htm. Date of access: 20.08.1996.

3.Association Greenhouses of Russia: preliminary results of 2019 [Web resource] URL: http://rusteplica.ru/predvaritelnye-itogigoda/. Date of access: 15.04.2020 (In Russ.).

4.Grishechkina L.D. Problems of protection of vegetable crops from diseases in greenhouses. Protection and quarantine of plants. 2011. № 2. Pp. 16-18 (In Russ.).

5.Ahatov A.K., Ahatov E.A. The Most harmful diseases of vegetable crops in modern greenhouses. Gavrish. 2014. №3. Pp. 16-23 (In Russ.).

6. Hadidi A., Khetarpal R.K., Koganezawa H. Plant virus disease control. Minnesota: The American Phytopathological Society, 1998. $684 \mathrm{p}$.

7.EPPO Global Database [Web resource] URL: https://gd.eppo.int/ datasheets/. Date of access: 15.04.2020.

8.Zerbini F.M. et al. ICTV Report Consortium (February 2017). ICTV Virus Taxonomy Profile: Geminiviridae. The Journal of General Virology. 2017. Vol. 98 (2). Pp. 131-133.

9.Gray, Banerjee N. Mechanisms of Arthropod Transmission of Plant and Animal Viruses. Microbiol Mol Biol Rev. 1999. Vol. 63 (1). Pp. 128-148.

10.Krupovic M., Ravantti J.J., Bamford D.H. Geminiviruses: a tale of a plasmid becoming a virus. BMC Evol Biol. 2009. Vol. 9 (112). doi:10.1186/1471-2148-9-112.

11.Discovery of ancient recombination between geminiviral DNA and the nuclear genome of Nicotiana sp. / E.R. Bejarano, A.M. Khashoggi, M. Witty, C.P. Lichtenstein. Proceedings of the National Academy of Sciences. 1994. Vol. 93. Pp. 759-764.

12.International Committee on Taxonomy of Viruses (ICTV) [Web resource] URL: https://talk.ictvonline.org/. Date of access: 15.04.2020.

13.Co-divergence and host-switching in the evolution of tobamoviruses / A.H. Stobbe, U. Melcher, M.W. Palmer, M.J. Roossinck, G. Shen. The Journal of General Virology. 2012. Vol. 93. Pt. 2. Pp. $408-418$.

14.Bujarski J. et al. ICTV Report, Consortium (August 2019). ICTV Virus Taxonomy Profile: Bromoviridae. The Journal of General Virology. 2019. Vol. 100 (8). Pp. 1206-1207.

15.Notes on Genus: Nepovirus [Web resource] URL: http://www. dpvweb.net/notes/showgenus. php?genus=Nepovirus. Date of access: 15.04.2020.

16.Nepoviruses (Picornavirales, Secoviridae, Nepovirus) in the South of the Far East: results of long-term monitoring / N.N. Kakareka, Z.N. Kozlovskaja, Ju.G. Volkov, T.I. Pleshakova, M.V. Sapockij, M.Ju. Sapockij. South of Russia: ecology, development. 2017. №4. Pp. 105-119 (In Russ.).

17.Wintermantel W.M., Wisler G.C. Vector specificity, host range and genetic diversity of Tomato chlorosis virus. Plant Dis. 2006. Vol. 90. Pp. 814-819.

18.Chang $\mathrm{Ha}$ Thi Kuin'. Distribution and pathogenesis of tomato virus diseases in Vietnam and Russia: abstract. ... Cand. Sci. (Biol.). Moscow, 2013. 20 p. (In Russ.).

19.Verbeek M. et al. Identification and characterisation of Tomato 
torrado virus, a new plant picorna-like virus from tomato. Arch. Virol. 2007. Vol. 152. Pp. 881-890.

20. First report of Tomato torrado virus infecting tomato in single and mixed infections with Cucumber mosaic virus in Panama / J.A. Herrera-Vasquez, A. Alfaro-Fernández, M.C. Córdoba-Selles, M.C. Cebrian, M.I. Font, C. Jordá. Plant Dis. 2009. Vol. 93. Pp. 198.

21.Zhivaeva T.S. Species composition of cucumber and tomato viruses in the European part of the Russian Federation. Materials of the 4th Congress on plant protection. Saint Petersburg: ARRIP, 2019. P. 76 (In Russ.).

22. Nikolić D. et al. Viruses affecting tomato crops in Serbia. European Journal of Plant Pathology 2018. Vol. 152. Pp. 225-235.

23.Lemmetty A., Laamanen J., Soukainen M. Emerging virus and viroid pathogen species identified for the first time in horticultural plants in Finland in 1997-2010. Agricultural and Food Science. 2011. Vol. 20. Pp. 29-41.

24.Commission Decision 2001/536/EC, 2004/200/EC [Web resource] URL: https://eur-lex.europa.eu/. Date of access: 15.04.2020.

25.Ahatov A.K. et al. Diseases and pests of vegetable crops and potatoes. Moscow: KMK, 2013. 463 p. (In Russ.).

26. Pyramiding of genes conferring resistance to Tomato yellow leaf curl virus from different wild tomato species / F. Vidavski, H. Czosnek, S. Gazit, D. Levy, M. Lapidot. Plant Breed. 2008. Vol. 127. Pp. 625-631.

\section{Об авторах}

Игнатов Александр Николаевич (ответственный за переписку), доктор биол. наук, зам. ген. директора по научной работе, ООО ИЦ «ФитоИнженерия», профессор, агробиотехнологический департамент, Аграрно-технологический институт, Российский Университет Дружбы народов. E-mail: an.ignatov@gmail.com

Гриценко Вячеслав Владимирович, профессор кафедры защиты растений, доктор биол. наук, ФГБОУ ВО РГАУ - МСХА имени К.А. Тимирязева. E-mail: vaceslavgricenkol@gmail.com

Джалилов Февзи Сеид-Умерович, доктор биол. наук, профессор, заведующий кафедрой защиты растений, ФГБОУ ВО РГАУ - МСХА им. К.А. Тимирязева. E-mail: labzara@mail.ru

\section{Author details}

Ignatov A.N. (author for correspondence), D. Sci. (Biol.), Deputy General Director for scientific work Research Centre «PhytoEngineering", professor of agrobiotechnological, Department Russian University of People's Friendship. E-mail: an.ignatov@gmail.com

Gritsenko V.V., D. Sci. (Biol.), professor, Department of Plant Protection, Russian State Agrarian University - Moscow Agricultural Academy by K.A. Timiryazev. E-mail: vaceslavgricenkol@gmail.com

Dzhalilov F. S-U. D. Sci. (Biol.), professor, head of Department of plant protection, Russian State Agrarian University - Moscow Agricultural Academy by K. A. Timiryazev. E-mail: labzara@mail.ru 